\title{
Effect of potassium and zinc on growth, yield and economics of sweet potato (Ipomoea batatas L.) cv. CO-34
}

\author{
Pravin Singh $^{1 *}$, Kavita Aravindakshan ${ }^{1}$, I. B. Maurya ${ }^{1}$, Jitendra Singh ${ }^{2}$, Bhim Singh ${ }^{3}$ and \\ M. K. Sharma ${ }^{4}$ \\ ${ }^{1}$ Department of Vegetable Science, College of Horticulture and Forestry, Agriculture University, Kota, Jhalawar- \\ 326023 (Rajasthan), INDIA \\ ${ }^{2}$ Department of Fruit Science, College of Horticulture and Forestry, Agriculture University, Kota, Jhalawar-326023 \\ (Rajasthan), INDIA \\ ${ }^{3}$ Department of Agriculture Statistics, College of Horticulture and Forestry, Agriculture University, Kota, Jhalawar \\ -326023 (Rajasthan), INDIA \\ ${ }^{4}$ Department of NRM, College of Horticulture and Forestry, Agriculture University, Kota, Jhalawar-326023 \\ (Rajasthan), INDIA \\ *Corresponding autor. E-mail: hortiveg511@gmail.com
}

Received: March 23, 2016; Revised received: November 9, 2016 Accepted: January 27, 2017

\begin{abstract}
A field experiment was conducted to study the effect of different levels of potassium and zinc on growth, yield and economics of sweet potato. The experiment was laid out on clay and loam soil by adopting randomized block design with factorial technique (FRBD). The sixteen treatments consisted of combination of four levels of potassium $(0,80,100$ and $120 \mathrm{~kg} / \mathrm{ha}$ through muriate of potash and four levels of foliar zinc (control i.e. water spray, 10,20 and $30 \mathrm{ppm}$ ) through zinc sulphate. The individual application of potassium $120 \mathrm{~kg} \mathrm{~K} \mathrm{O}_{2} \mathrm{O} / \mathrm{ha}$ significantly increased the number of tubers per plant (4.60), average weight of tuber $(275.31 \mathrm{~g})$, length of tuber $(16.77 \mathrm{~cm})$, diameter of tuber $(5.69 \mathrm{~cm})$, tuber yield per plot $(9.71 \mathrm{~kg})$, tuber yield per hectare $(49.04 \mathrm{t})$ respectively as compared to control. With the foliar application of zinc $(30 \mathrm{ppm})$ significant increase in number of tubers per plant (4.18), average weight of tuber $(234.73 \mathrm{~g})$, length of tuber $(18.12 \mathrm{~cm})$, diameter of tuber $(5.16 \mathrm{~cm})$, tuber yield per plot $(8.33 \mathrm{~kg})$ and tuber yield per hectare $(42.05 \mathrm{t})$ was recordedas compared to control The treatment combination $(120 \mathrm{~kg}$ $\left.\mathrm{K}_{2} \mathrm{O}+30 \mathrm{ppm} \mathrm{Zn}\right)$ recorded the maximum yield parameters i.e. chlorophyll content $(37.00 \mathrm{mg} / 100 \mathrm{~g})$, average weight of tuber $(302.17 \mathrm{~g})$, length of tuber $(19.82 \mathrm{~cm})$, diameter of tuber $(5.97 \mathrm{~cm})$, maximum tuber yield per plot $(11.02 \mathrm{~kg})$, tuber yield per hectare $(55.67 \mathrm{t})$ and benefit-cost ratio $\left(\mathrm{B}: \mathrm{C}\right.$ ratio) of $4.22: 1$. While, the treatment $\left(120 \mathrm{~kg} \mathrm{~K}{ }_{2} \mathrm{O}+30 \mathrm{ppm}\right.$ $\mathrm{Zn}$ ) had the maximum number of tuber (4.86), minimum number of tuber was recorded in control. From the experiment, it appeared that application of potassium and zinc can be used to improve yield and higher net monetary returns of sweet potato.
\end{abstract}

Keywords: Growth, Potassium, Sweet potato, Zinc, Yield

\section{INTRODUCTION}

Sweet potato (Ipomoea batatas L.) is an herbaceous dicotyledonous plant with creeping, perennial vines and adventitious roots and belongs to the family Convolvulaceae (morning glory) and is one of the important tuber crops of tropical and subtropical regions of the World. It is believed to have originated in Central America and the North Western part of South America. In India, it is the third most important tuber crop after potato and cassava. Globally, India occupies twelfth, eighth and fifth rank in area, production and productivity respectively. It is cultivated predominantly as a rainfed crop in Eastern India, especially in Orissa, West Bengal, Uttar Pradesh, Bihar and Jharkhand, accounting for $77 \%$ of area and $82 \%$ of production (Edison et al., 2009). The total area in the world under sweet potato is estimated to be 7.95 million ha with a production of 104.26 million tonnes. In India, sweet potato covers 1.12 lakh hectare areas, producing 11.32 lakh tonnes tubers, with the productivity of 10.1 metric tonnes per hectare (Anonymous, 2014). Rajasthan contributes only 0.50 thousand hectare area under sweet potato cultivation with production of 1.64 thousand MT of tuber and Productivity 3.28 Production/ha. (Anonymous, 2014). Potassium is a part of many important regulatory roles in the plant (Cakmak, 2005). It is essential macronutrients and has a wide range of functions in plant growth and development, including cell extension, stomata movement, and control of ionic balance, enzyme activation, photosynthesis, protein synthesis, phloem loading and transport, and tolerance of external stress (Marschner 2012 and Zörb, et al. 2014). Potassium appears to be the most important 
nutrient in the production of sweet potato as its application increases yield by the formation of larger sized tubers. Potassium also influences the number, size, quality and the unit weight of tuberous roots produced, while the minimum levels of potassium is suggested for healthy growth and yield (Degras, 2003). Apart from potassium as major nutrients, micronutrients also form a constituent part of plant. Proper supply of these nutrients is sure to increase yield and positive effect on crop production. With a shortage of potassium many metabolic processes are affected, such as the rate of photosynthesis, the rate of translocation and enzyme systems and deficiency symptoms first appear on older (lower) leaves because potassium is a mobile nutrient, meaning that a plant can allocate potassium to younger leaves. Potassium appears to be the most important nutrient in the production of sweet potato as its application increases yield by the formation of larger sized tubers (Uwah et al., 2013). Potassium chloride $(\mathrm{KCl})$, known also as muriate of potash (MOP), is the most widely used source of potassium for agricultural crops (DEFRA, 2010).

The micronutrients on the other hand though are required in small amount but play a great role in plant metabolism (Katyal, 2004 and Kazi et al., 2012). Zinc is an essential micronutrient which plays a macro role in the growth and productivity of the plants. $\mathrm{Zn}$ is an important component of enzymes that drive and increase the rate of many important metabolic reactions involved in crop growth and development (Potarzycki and Grzebisz, 2009). The symptoms of zinc deficiency are visible generally in younger leaves, starting from inter-veinalchlorosis resulting to a decrease in shoot development and shortening of internodes, mottle leaf, little leaf etc (Kiran, 2006). Sweet potato plants responded positively to foliar application of zinc and produced maximum production of roots (Abd El-baky et al., 2010). The aim of this work is to investigate effect of potassium and zinc on growth and yield of sweet potato as till traditional practices is followed as it invites low yield. Keeping this in view of the tuber formation and tuber size of sweet potato in information on the above mentioned aspects, the present investigation entitled "effect of potassium and zinc on growth, yield and economic on sweet potato (Ipomoea batatas L) cv. CO-34" was undertaken.

\section{MATERIALS AND METHODS}

The field experiment was conducted during rabi 20142015 at Department of Vegetable Science, College of Horticulture and Forestry, Jhalawar (Rajasthan) to study the effect of potassium and zinc on growth, yield and economics of sweet potato. The soil of the site belongs to order Vertisol (USDA, 2010 Classification). The experimental initial soil status was $\mathrm{pH} 6.67$, EC $0.56 \mathrm{dSm}^{-1}$, available nitrogen $218.3 \mathrm{~kg} / \mathrm{ha}$ (Subbiah and Asija, 1956), available phosphorus $28.01 \mathrm{~kg} / \mathrm{ha}$ (Olsen et al., 1954) and available potash $210.60 \mathrm{~kg} / \mathrm{ha}$ (Metson,1956) and organic carbon 0.58 per cent (Walkley and Black,1934). Experiments were laid out in a randomized block design (FRBD) with factorial technique and three replications. The 16 treatments consisted of combination of four levels of potassium $(0,80,100$ and $120 \mathrm{~kg} /$ ha through muriate of potash and four levels of foliar zinc (control i.e. water spray, 10, 20 and 30ppm) through zinc sulphate. Zinc was two foliar applications at 45 and 90 days after transplanting (DAT). The recommended dose of fertilizer (RDF) was applied for sweet potato $(50: 60 \mathrm{~N}$ : $\mathrm{P}_{2} \mathrm{O}_{5} \mathrm{~kg} \mathrm{ha}{ }^{-1}$ ) as per the treatments. The crop was grown on raised beds at $60 \times 30 \mathrm{~cm}$ spacing on drip system. Each treatment consisted of 10 plants for which 10-cutting were sown in a two rows of 1.5 meter length. The observations were recorded on seven characters namely number of leaves per plant (45 DAT and $90 \mathrm{DAT})$, chlorophyll content (mg/100g), number of tubers/plant, average weight of tubers/plant and volume of tuber per plant (cc),tubers yield per plot $(\mathrm{kg})$, and tubers yield per hectare(t).The data was subjected to analysis of variance (ANOVA) for testing the significance of variation due to potassium, zinc and their interaction for different characters as described by Gomez and Gomez (1984). Mean values were calculated and compared using F-test at 5\% level of significance.

\section{RESULTS}

Growth parameters: An appraisal of the data presented in Table 1 indicated that potassium and zinc application significantly increased number of leaves per plant. The number of leaves per plant, at 45DAT and at harvest was significantly higher by 91.37 and 455.55 respectively due to application of treatment $\mathrm{K}_{3}$ (120 kg K $\mathrm{K}_{2} \mathrm{O} / \mathrm{ha}$ ) as higher than the control. The maximum number of leaves per plant i.e., 65.57 and 412.08 at 45 DAT and at harvest respectively was observed in treatment $\mathrm{Zn}_{3}$ (30ppm). However, the interaction effect of potassium and zinc levels was found non-significant with respect to number of leaves per plant (Table 2)

A perusal of data displayed in Table 1 and Table 2 shows that application of potassium and zinc increased chlorophyll content over control. Application with 120 $\mathrm{kg} \mathrm{K}_{2} \mathrm{O} /$ ha had significantly maximum chlorophyll $(33.80 \mathrm{mg} / 100 \mathrm{~g})$ than control $(29.93 \mathrm{mg} / 100 \mathrm{~g})$. Also the foliar application of $30 \mathrm{ppm}$ zincgave the highest chlorophyll content $(33.87 \mathrm{mg} / 100 \mathrm{~g})$. Whereas, the application of $0 \mathrm{ppm}$ zinc showed significantly the lowest chlorophyll content $(31.51 \mathrm{mg} / 100 \mathrm{~g})$. The maximum chlorophyll content(36.34 mg/100g) was recorded in $120 \mathrm{Kg} \mathrm{K} \mathrm{K}_{2} \mathrm{O} / \mathrm{ha}$ and $\mathrm{Zn} \mathrm{30ppm} \mathrm{as}$ compared to control $(28.32 \mathrm{mg} / 100 \mathrm{~g})$.

Yield parameters: Number of tuber per plant, average 


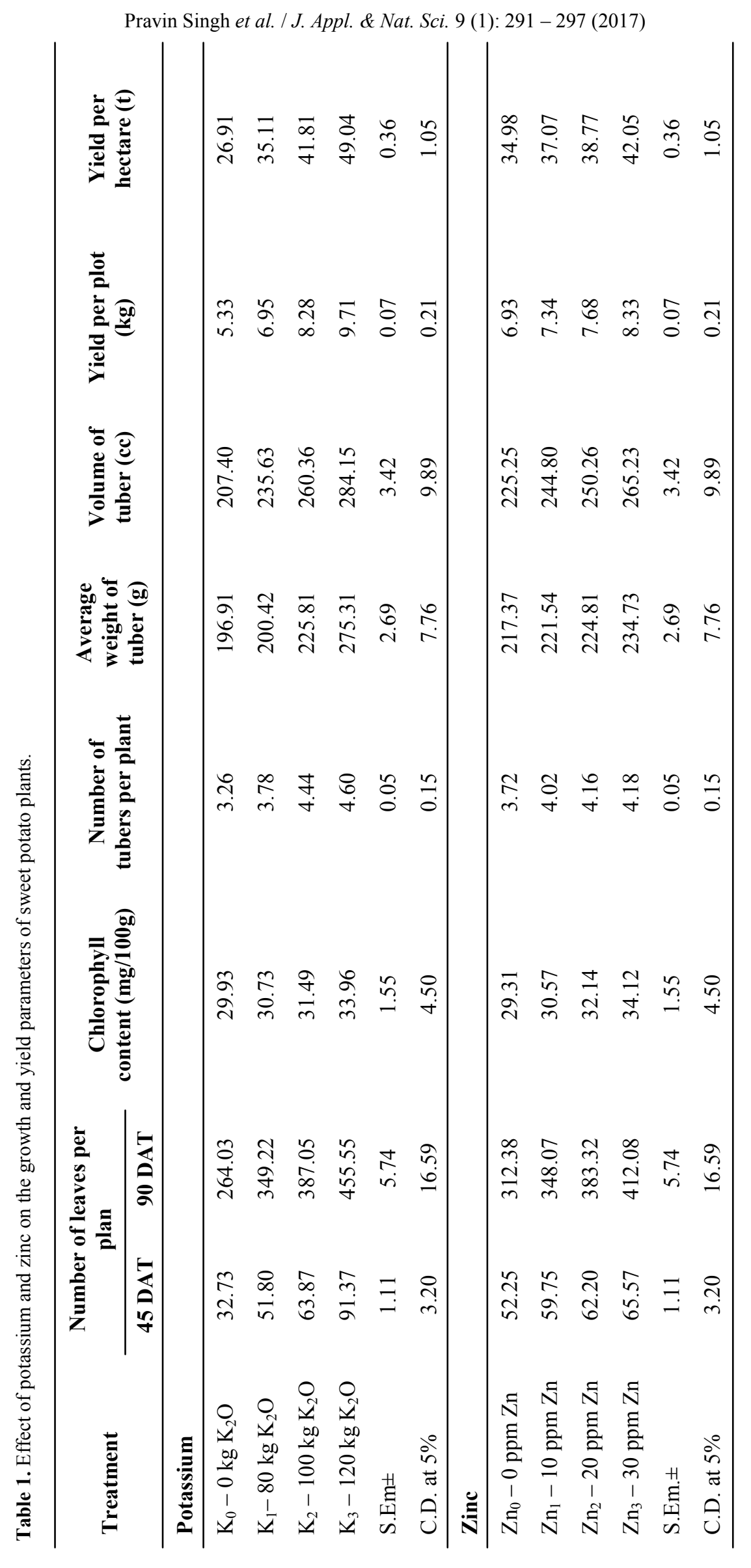




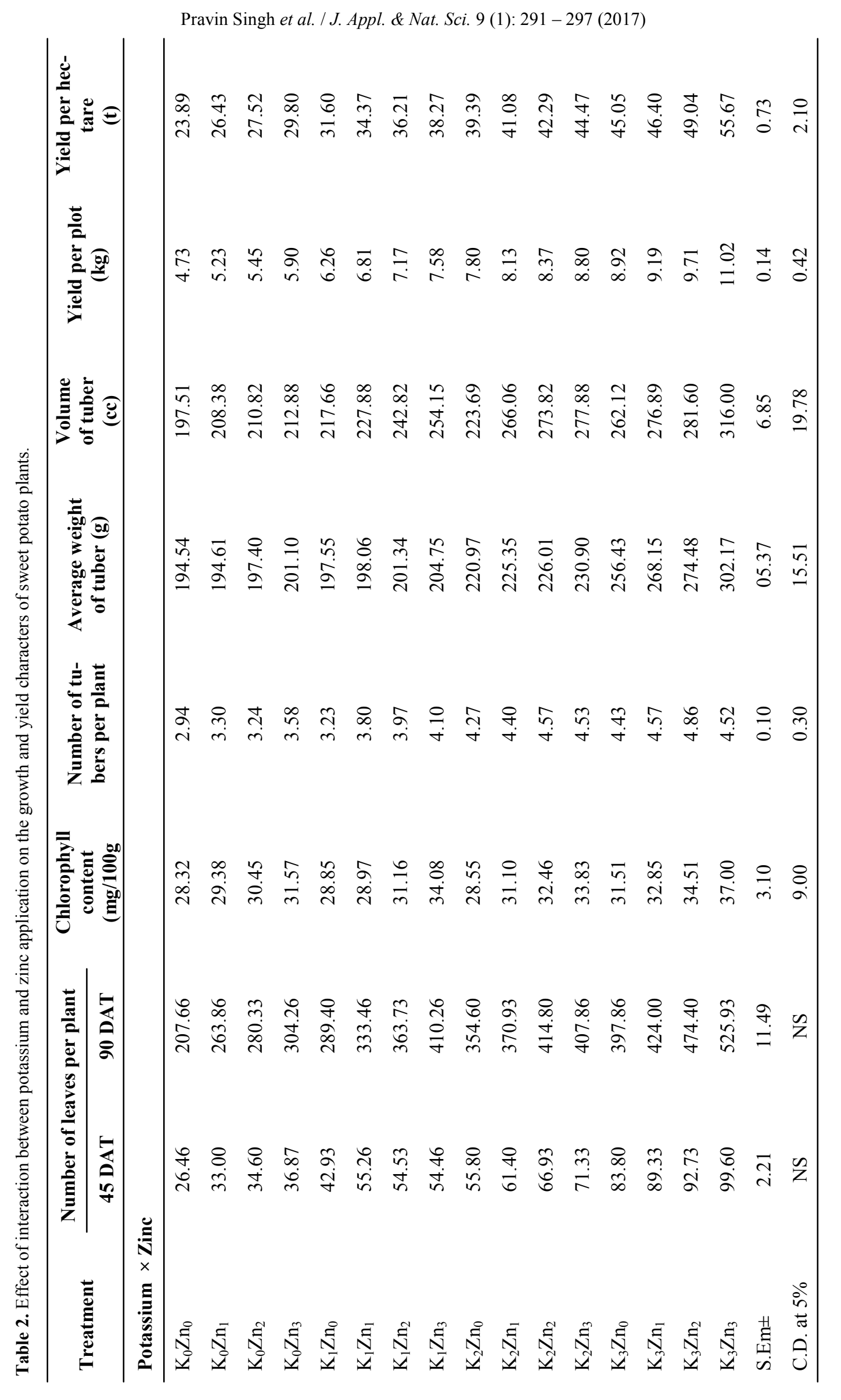


weight of tuber and volume of tuber increased with increasing levels of potassium were significant under $120 \mathrm{~kg} \mathrm{~K}_{2} \mathrm{O} \mathrm{ha}^{-1}$ as compared to control (Table 1). The percent increase in number of tuber, average weight of tuber and volume of tuber with the application of 120 $\mathrm{kg} \mathrm{ha}^{-1}$ was observed to be $41.10,39.81$ and 37.00 over control. Increase in the number of tuber per plant, average weight of tuber and volume of tuber with application of $30 \mathrm{ppm} \mathrm{Zn}$ was found to be significant over control. Combined application of potassium and zinc showed significant increase in respect to yield attributes. The treatment combination $\mathrm{K}_{3} \mathrm{Zn}_{3}(120 \mathrm{~kg}$ $\mathrm{K}_{2} \mathrm{O}+30 \mathrm{ppm} \mathrm{Zn}$ ) recorded the maximum average weight of tuber $(207.40 \mathrm{~g})$ and volume of tuber $(284.15 \mathrm{cc})$ While, the treatment $\mathrm{K}_{3} \mathrm{Zn}_{2}(120 \mathrm{~kg}$ $\mathrm{K}_{2} \mathrm{O}+20 \mathrm{ppm} \mathrm{Zn}$ ) had the maximum number of tuber (4.86) thought minimum number of tuber was recorded in $\mathrm{K}_{0} \mathrm{Zn}_{0}$ (control).

Significant increase in tuber yield per plot and tuber yield per hector was observed with increasing levels of potassium up to $120 \mathrm{~kg} \mathrm{~K}_{2} \mathrm{O} \mathrm{ha}{ }^{-1}$. Application of 120 $\mathrm{kg} \mathrm{K} \mathrm{K}_{2} \mathrm{O} \mathrm{ha}^{-1}$ produced the maximum tuber yield per plot and tuber yield per hectareof $9.71 \mathrm{~kg}$ and $49.04 \mathrm{t} \mathrm{ha}^{-1}$, representing significant increase of 82.17 and $82.23 \%$ over control, respectively (Table-1). Tuber yield per plot and tuber yield per hector influenced significantly with $30 \mathrm{ppm} \mathrm{Zn}$ as compared to control. The combined application of $\mathrm{K}$ and $\mathrm{Zn}$ significantly increased the tuber yield per plot and tuber yield per hector (Table 2). Maximum tuber yield per plot of $11.02 \mathrm{~kg}$ and tuber yield per hectare of $55.67 \mathrm{t} \mathrm{ha}^{-1}$ was obtained with $120 \mathrm{~kg} \mathrm{~K}_{2} \mathrm{O}$ ha ${ }^{-1}$ plus $30 \mathrm{ppm} \mathrm{Zn} \mathrm{which}$ was $4.73 \mathrm{~kg}$ and $23.89 \mathrm{t} \mathrm{ha}^{-1}$ additional over control. Data depicted in Table -3 showed that maximum net returns (Rs. $225039.30 \mathrm{ha}^{-1}$ ) and B: C ration (4.22) from sweet potato was obtained with potassium $120 \mathrm{~kg}$ $\mathrm{ha}^{-1}$ and $30 \mathrm{ppm}$ zinc.

\section{DISCUSSION}

Generally, the application of potassium at higher rates significantly increased number of leaves per plant, chlorophyll content, number of tubers/plant and average weight of tubers/plant in the trial. This positive response of growth characters to the applied $\mathrm{K}$ is attributable to its role in cell multiplication and photosynthesis in conjunction with $\mathrm{N}$, which gave rise to increase in number of leaves and chlorophyll content of leaves. In this respect, Liu (2013) studied that effect of application of $\mathrm{K}_{2} \mathrm{O}$ at $24 \mathrm{gm}^{2}$ soils on distribution of photosynthates in plants of sweet potatowals improved the chlorophyll content in the early growth stage. Cao and Tibbittis (1991) found that different $\mathrm{K}$ concentrations gave significant chlorophyll in potato leaves compared to control treatment. Moreover, $\mathrm{K}$ is also essential to the performance of multiple plant enzyme functions, and it regulates the metabolite pattern of higher plants, ultimately changing metabolite concentrations (Mengel, 2001 and Marschner, 2012). The positive response shown by yield characters to $\mathrm{K}$ could be directly linked to the well-developed photosynthetic surfaces (number of leaves, number of branches and chlorophyll) and increased physiological activities leading to more assimilates being produced and subsequently translocated and utilized in rapid tuber development and production. Marschner (2012) reported that $\mathrm{K}$ plays a crucial role in turgor regulation within the guard cells during stomatal movement. Potassium is an important nutrient for plant meristematic growth and physiological functions, including regulation of water and gas exchange in plants, protein synthesis, enzyme activation, photosynthesis and carbohydrate translocation in plants. Furthermore, $\mathrm{K}$ is also essential for the translocation of photo assimilates in root growth also root growth promotion by increased appropriate $\mathrm{K}$ supply under K deficient soil was found to increase the root surface that was exposed to soil as a result of increased root water uptake (Romheld and Kirkby, 2010).According to the results obtained from the research of Ummar and Moinuddin (2001) potassium application upto $120 \mathrm{~kg} \mathrm{~K} 2 \mathrm{O} /$ ha led to increased tuber yield. Also regarding tuber yield as a result of potassium $150 \mathrm{~kg} \mathrm{~K}_{2} \mathrm{O}$ /ha application experiment of Moinuddinet al. (2005). Similarly potassium has been reported that application of $\mathrm{K}_{2} \mathrm{O}$ at 150 and $200 \mathrm{~kg} \mathrm{~K}$ $\mathrm{ha}^{-1}$ significantly increased marketable tuber and fresh tuber yield of sweet potato (Sokotoet al. 2007). Similar finding was recorded by (Lu et al., 2001 and Uwahet al., 2013) in sweet potato crop. Finally, it could conclude that increase in the potassium fertilization mainly increased yield through the formation of large sized tubers, total number of tubers and their translocation to some extent to the sweet potato.

Zinc is a micronutrient which is required for plant growth and development relatively in small amount. Zinc plays a fundamental role in several critical functions in the cell such as protein metabolism, gene expression, structural and functional integrity of bio membranes and photosynthetic carbon metabolism (Cakmak, 2000). Zinc is main building part of some enzymes viz. alcohol dehydrogenase, carbonic anhydrase, superoxide dismutase that is needed for the root development and increasing the absorption of carbon dioxide per leaf area unit and this increasing the photosynthesis and biomass production and yield (Pedleret al., 2000,Vitoshet al., 1994 and Marschner, 1995) This increase could be due to the fact that $\mathrm{Zn}$ plays an important role in regulating the auxin concentration in plants and is an essential component of enzymes which promotes the growth and development of plants. It may also be pointed out that growth and development of plants depend upon physiological and metabolic activity of plants influenced by application of zinc. Sweet potato plants responded positively to 
Table 3. Economic feasibility of potassium and zinc treatment in sweet potato cv. 'CO-34'.

\begin{tabular}{|c|c|c|c|c|}
\hline Treatment & $\begin{array}{c}\text { Treatment Cost } \\
\left(₹ \mathrm{ha}^{-1}\right)\end{array}$ & $\begin{array}{l}\text { Gross returns } \\
\left(₹ \text { ha }^{-1}\right)\end{array}$ & $\begin{array}{l}\text { Net returns } \\
\left(₹ \text { ha }^{-1}\right)\end{array}$ & $\begin{array}{c}\text { Benefit cost ratio } \\
\text { (BCR) }\end{array}$ \\
\hline $\mathrm{T}_{0}\left(0 \mathrm{Kg} \mathrm{K}_{2} \mathrm{O}+0 \mathrm{ppm} \mathrm{Zn}\right)$ & 49740.23 & 119434.53 & 69694.30 & 1.40 \\
\hline $\mathrm{T}_{1}\left(0 \mathrm{Kg} \mathrm{K}_{2} \mathrm{O}+10 \mathrm{ppm} \mathrm{Zn}\right)$ & 49797.11 & 132126.22 & 82329.11 & 1.65 \\
\hline $\mathrm{T}_{2}\left(0 \mathrm{Kg} \mathrm{K}_{2} \mathrm{O}+20 \mathrm{ppm} \mathrm{Zn}\right)$ & 49853.99 & 137624.48 & 87770.49 & 1.76 \\
\hline $\mathrm{T}_{3}\left(0 \mathrm{Kg} \mathrm{K}_{2} \mathrm{O}+30 \mathrm{ppm} \mathrm{Zn}\right)$ & 49910.87 & 149023.63 & 99112.76 & 1.99 \\
\hline $\mathrm{T}_{4}\left(80 \mathrm{Kg} \mathrm{K}_{2} \mathrm{O}+0 \mathrm{ppm} \mathrm{Zn}\right)$ & 52006.84 & 158013.21 & 106006.37 & 2.04 \\
\hline $\mathrm{T}_{5}\left(80 \mathrm{Kg} \mathrm{K}{ }_{2} \mathrm{O}+10 \mathrm{ppm} \mathrm{Zn}\right)$ & 52063.72 & 171866.53 & 119802.81 & 2.30 \\
\hline $\mathrm{T}_{6}\left(80 \mathrm{Kg} \mathrm{K}_{2} \mathrm{O}+20 \mathrm{ppm} \mathrm{Zn}\right)$ & 52120.6 & 181032.35 & 128911.75 & 2.47 \\
\hline $\mathrm{T}_{7}\left(80 \mathrm{Kg} \mathrm{K}_{2} \mathrm{O}+30 \mathrm{ppm} \mathrm{Zn}\right)$ & 52177.48 & 191329.98 & 139152.50 & 2.67 \\
\hline $\mathrm{T}_{8}\left(100 \mathrm{Kg} \mathrm{K}_{2} \mathrm{O}+0 \mathrm{ppm} \mathrm{Zn}\right)$ & 52573.45 & 196954.00 & 144380.55 & 2.75 \\
\hline $\mathrm{T}_{9}\left(100 \mathrm{Kg} \mathrm{K}_{2} \mathrm{O}+10 \mathrm{ppm} \mathrm{Zn}\right)$ & 52630.33 & 205408.16 & 152777.83 & 2.90 \\
\hline $\mathrm{T}_{10}\left(100 \mathrm{Kg} \mathrm{K}_{2} \mathrm{O}+20 \mathrm{ppm} \mathrm{Zn}\right)$ & 52687.21 & 211466.49 & 158779.28 & 3.01 \\
\hline $\mathrm{T}_{11}\left(100 \mathrm{Kg} \mathrm{K}_{2} \mathrm{O}+30 \mathrm{ppm} \mathrm{Zn}\right)$ & 52744.09 & 222346.54 & 169602.45 & 3.22 \\
\hline $\mathrm{T}_{12}\left(120 \mathrm{Kg} \mathrm{K}_{2} \mathrm{O}+0 \mathrm{ppm} \mathrm{Zn}\right)$ & 53140.06 & 225259.87 & 172119.81 & 3.24 \\
\hline $\mathrm{T}_{13}\left(120 \mathrm{Kg} \mathrm{K}_{2} \mathrm{O}+10 \mathrm{ppm} \mathrm{Zn}\right)$ & 53196.94 & 232021.88 & 178824.94 & 3.36 \\
\hline $\mathrm{T}_{14}\left(120 \mathrm{Kg} \mathrm{K}_{2} \mathrm{O}+20 \mathrm{ppm} \mathrm{Zn}\right)$ & 53253.82 & 245224.93 & 191971.11 & 3.60 \\
\hline $\mathrm{T}_{15}\left(120 \mathrm{Kg} \mathrm{K}_{2} \mathrm{O}+30 \mathrm{ppm} \mathrm{Zn}\right)$ & 53310.7 & 278350.00 & 225039.30 & 4.22 \\
\hline
\end{tabular}

Sale price of sweet potato @ ₹ 5.00/kg.

foliar application Zn@(10 to 30 ppm) and the highest production of roots was obtained with the highest zinc dose as indicated by Abd EI-Baky et al. (2010). Appreciable increase in sweet potato yield by foliar application of $\mathrm{Zn}$ was reported by George and Mittra (1996) in the trials conducted at Kharagpur in West Bengal. In another finding Singh and Singh (2004) observed the beneficial of zinc (0,10, 20 and $30 \mathrm{ppm})$ at 30 and 60 DAT in increasing the yield and quality of cauliflower.

Potassium has also an important role in improving sweet potato yield as indicate by Abd EI-Baky et al. (2010) who found that the maximum estimated sweet potato yield was obtained with combination of the rate of $120 \mathrm{~kg} \mathrm{~K}_{2} \mathrm{O} /$ fed applied to the application of $30 \mathrm{ppm}$ zinc. Moreover, El-Hadidi and Mansour (2008) found that application of potassium $48 \mathrm{~kg} / \mathrm{fed}$ combined with foliar application of zinc at the rate of $30 \mathrm{ppm}$ gave the highest total tubers yield of sweet potato plants. The interaction effect of potassium and zinc responded synergistic relationship to $\mathrm{K}$ and $\mathrm{Zn}$ increasing rate (Malvi, 2011). This positive effect may be attributed to the increasing $\mathrm{K}$ availability in soil. In addition, $\mathrm{K}$ is a key factor in regulating plant water status (Marschner, 1995), which reflects on plant growth and hence yield
Thus, the combined application of potassium and zinc provided all the essential nutrients, required by plants for its growth and development. It was suggested that, $\mathrm{Zn}$ is involved in stomatal opening, possibly as a constituent of the enzyme carbonic anhydrase and/or as a factor in maintaining membrane integrity and $\mathrm{K}^{+}$ uptake (Sharma et al., 1995).

\section{Conclusion}

On the basis of experimental findings it can be concluded that external application of potassium and zinc either singly or in combination produced the vital effect on various yield parameters. But growth parameters (number of leaves per plant) was remaining uninfluenced after application of potassium and zinc in combinations. The application of $(120 \mathrm{~kg} \mathrm{~K} 2 \mathrm{O} / \mathrm{ha}+30 \mathrm{ppm}$ $\mathrm{Zn}$ ) has recorded for higher productivity and economic returns from in the study area of sweet potato.

\section{ACKNOWLEDGMENTS}

I wish to thank everyone who helped me in complete this dissertation. Without their continued help and support, I would have not been able to bring my work to a successful completion. The authors are grateful to the Dean and all staff of College of Horticulture and 
Forestry, Jhalawar, for providing the necessary research facilities.

\section{REFERENCES}

Abd El-Baky, M.M.H., Ahmed, A.A., El-Nemr, M.A. and Zaki, M.F. (2010).Effect of potassium fertilizer and foliar zinc application on yield and quality of sweet potato.J. of Agric. and Bio. Sci.,6(4):386-394

Anonymous, (2014).Indian Horticulture Database, National Horticulture Board, Gurgaon pp.194-197

Cakmak I. (2000): Possible role of zinc in protecting plant cells from damage by reactive oxygen species. New Phytologist, 146: 185-205

Cakmak, I. (2005). The role of potassium in alleviating detrimental effects of abiotic stresses in plants. J. Plant Nutr. Soil Sci., 168:521-530

Cao, W. and T.W. Tibbitts, (1991).Potassium concentration effect on growth, gas exchange and mineral accumulation in potatoes. Journal of plant nutrition, 14 (6), 525- 537.

DEFRA (2010). Fertiliser manual (RB209) (8th ed.). Norwich: TSO, London.

Degras, L. (2003). Sweet potato. The Tropical Agriculturalist. Malaysia: Macmillan Publishers Ltd.

Edison, S., Hegde, V., Makesh Kumar, T., Srinivas, T., Suja, G. and Padmaja, G. (2009).Sweepotato in the Indian sub continent. In:The Sweet Potato. Lobenstein, G. and Thottappilly, G. (Eds.). Springer Science Publishers, pp.391-414.

El-Hadidi, E.M. and Mansour, M.M. (2008). Effect of potassium and zinc fertilization on growth, nutrients contents and yield. J. of Agric. Sci., 33(6):4589-4608

George, J. and Mittra, B.N. (1996).Effect of application of ash and paper factory sludge as source of micronutrients on the performance of sweet potato. In: Tropical Tuber Crops in Food Security and Nutrition. Balagopalan, C., Nayar, T.V.R., Sundaresan, S., Premkumar, T. and Lakshmi, K.R. (Eds.).Oxford \& IBH Publishing Co. Pvt. Ltd., New Delhi. pp. 338-343.

Gomez, K. A. and Gomez, A. A. (1984). Statistical Procedures for Agricultural Research, Second edition, A Wiley Interscience Publication, New York, USA.

Katyal, J.C. (2004).Role of micronutrients in ensuring optimum use of macronutrients.IFA International symposium on micronutrients, New Delhi, India pp 3-17.

Kazi, S.S., Syed Ismail and Joshi K.G. (2012). Effect of multi -micronutrient on yield and quality attributes of sweet orange. African J. of Agric. Res., 7(29):4118-23.

Kiran, J. (2006). Effect of fertilizer, bio-fertilizer and micro-nutrients on seed yield and quality of brinjal (Solanum melongena L.). Department of seed science and technology college of agriculture, Dharwad, (India) pp. 1-2.

Lu, J. W., Chen, F., Xu, Y., Wan, Y.F. and Liu, D.B. (2001). Sweet potato response to potassium Better Crops International; $15(1): 10-12$

Malvi, U.R. (2011). Interaction of micronutrients with major nutrients with special reference to potassium. Karnataka J. Agric. Sci., 24(1) :106-109

Marschner, H. (1995). Functions of mineral nutrients: macronutirents, In: H. Marschner (ed.). Mineral nutrition of higher plants $2^{\text {nd }}$ Edition. Academic Press, N.Y. London p. 299-312.

Marschner, P., (2012). Mineral Nutrition of Higher Plants, 3rd ed.; Academic Press: London, UK,; pp. 178-189

Mengel, K. and Kirkby, E.A. (2001).Principles of Plant Nutrition. $5^{\text {th }}$ ed., Kluwer Academic Publishers, Dordrecht.

Metson, A. J. (1956). Methods of chemical analysis for soil survey samples. Department of Science Md. Res. Soil Bur. pp. 12.

Moinuddin, Singh K., Bansal S.K., (2005). Growth, yield, and economics of potato in relation to progressive application of potassium fertilizer. - Journal of Plant Nutrition, 28: 183-200

Olsen, S. R., Cole, C. S., Wantable, F. S. and Dean, C. A., (1954). Estimation of available phosphorus in soils by extraction with sodium bicarbonate U.S.D.A., Washington, D.C. Circular.18: 939

Pedler, J.F., Parker, D.R. and Crowley, D.E. (2000). Zinc Deficiency-induced phytosiderophore release by the Triticaceae is not consistently expressed in solution culture. Planta, 211: 120-126

Potarzycki, J. and W. Grzebisz.(2009). Effect of zinc foliar application on grain yield of maize and its yielding components.Plant Soil Environ. 55(12): 519-527

Romheld, V. and E.A. Kirkby, (2010). Research on potassium in agriculture: Needs and prospects. Plant Soil, 335, 155-180

Sharma, P. N., Tripathi A. and Bisht, S. S. (1995). Zinc requirement for stomatal opening in cauliflower. Plant Physio.,107: 751-756

Singh, S. and Singh, P. (2004). Economic viability of foliar application of nitrogen and zinc in cauliflower (Brassica oleracea var. botrytis L.). Scientific Horticulture, 9:237-239.

Sokoto, M. B., Magaji, M. D. and A. Singh, A. 2007.Growth and Yield of Irrigated Sweet Potato (Ipomoea batatas Lam.) As Influenced by Intra-Row Spacing and Potassium. Journal of Plant Sciences, 2: 54-60

Subbiah, B.V. and Asija, G.L. (1956).A rapid plrocedure for the estimation of available nitrogen in soils. Current Sci., 126: 244-253

Umar S. Amd Moinuddin (2001). Effect of sources and rates of potassium application on potato yield and economic returns. Better Crops, 15: 13-15

USDA (2010).Keys to Soil Taxonomy, $10^{\text {th }}$ Ed., Soil Survey Staff, Natural Resources Conservation Service, USDA, USA.

Uwah, D.F., Undie, U.L., John , N.M., and Ukoha, G.O. (2013). Growth and yield response of improved sweet potato varieties to different rates of potassium fertilizer in Calabar, Nigeria J. of Agric. Sci., 5(7) 61-69

Vitosh, M.L., Warncke, D.D. and Lucas, R.E. (1994). Zinc determine of crop and soil. Michigan State University Extension.

Walkley, A. and Black, I. A. (1934).An examination of Degtjareff method for determining soil organic matter and a proposed modification of the chromic acid titration method. Soil Sci., 37:29-37

Zörb C., Senbayram M. and Peiter E. (2014). Potassium in agriculture - Status and perspectives. Journal of Plant Physiology, 171: 656-669 